\title{
FAKTOR FINANCIAL-NON FINANCIAL DAN TINGKAT PENGUNGKAPAN ISLAMIC SOCIAL REPORTING (ISR)
}

\author{
Anita Anggraini \\ CV. Atkomindo Dinamika \\ Email:quu.anita42@gmail.com \\ Mulyaning Wulan \\ Program Studi Akuntansi Syariah \\ Sekolah Tinggi Ekonomi Islam SEBI
}

\begin{abstract}
This study examines financial factors namely Size, Profitability and Leverage as well as non-financial factors, namely Industrial Type and Size of Board of Commissioner that affect the level of disclosure of ISR. ISR (Islamic Social Reporting) is an index of social responsibility disclosure in accordance with Islamic principles. For users of corporate reports that Muslims, disclosure of social responsibility is a form of accountability to Allah and is also used as one of the sources of information taken into consideration. Therefore, the object of observation in this study is Jakarta Islamic Index (JII), which is an index that describes Islamic stocks in Indonesia. The results of this study demonstrate that the Company Size, Profitability, Leverage, Industry Type, and Size of Board of Commissioners has a significant positive effect on the level of disclosure of ISR.
\end{abstract}

Keywords: Islamic Social Reporting, Jakarta Islamic Index, Financial Factors, Non Financial Factors.

\section{PENDAHULUAN}

Dewasa ini, praktik pengungkapan tanggung jawab sosial perusahaan atau yang lebih sering kita kenal dengan Corporate Social Responsibility (yang selanjutnya disebut sebagai CSR) merupakan salah satu hal yang menjadi sorotan penting dalam beberapa tahun belakangan ini. Kepedulian atas krisis sosial dan lingkungan saat ini telah menjadi isu yang hangat diperbincangkan di tengah revolusi industri dunia yang kian berkembang (Widiastuti, 2014, hlm. 1).

Pada dasarnya, keterkaitan perusahaan yang semakin besar terhadap lingkungan sosial, antara lain disebabkan oleh semakin besarnya sosial needs dan sosial expectations. Perlu dingat bahwa kebutuhan sosial merupakan salah satu kebutuhan manusia dalam kehidupannya. Davis dan Frederick dalam Asri (1996) dalam Widaryanti (2007) mensinyalir bahwa seiring dengan perbaikan kondisi ekonomi dunia pada umumnya, sosial expectation juga meningkat dramatis sejak tahun 1960-an sehingga sosial challenge bagi dunia usaha juga semakin bertambah. Tantangan sosial ini terutama meliputi perhatian yang seimbang terhadap sumber daya, etika dan ekonomi, sampai pada keseimbangan terhadap ekologi. Dengan kata lain, respon sosial sangat 
diperlukan untuk memperkecil jurang yang memisahkan perusahaan dengan lingkungan sosialnya.

Pemerintah juga telah mendukung praktik dan pengungkapan CSR ini dengan dikeluarkannya Undang-Undang Nomor 40 Tahun 2007 Pasal 74 tentang Perseroan Terbatas, pemerintah tidak hanya mewajibkan PT yang bergerak dalam bidang usaha sumber daya alam untuk menyisihkan dana dan melaksanakan program-program CSR. Tapi, juga mewajibkan semua PT menyertakan informasi CSR dalam laporan tahunan direksi kepada RUPS pada Pasal 66.

Undang-Undang lain yang mewajibkan perusahaan untuk melaksanakan tanggung jawab sosialnya adalah Undang-Undang Nomor 25 Tahun 2007 tentang penanaman modal, baik penanaman modal dalam negeri ataupun penanaman modal asing. Dalam Undang-Undang tersebut, disebutkan pada pasal 15 poin (b) bahwa setiap penanam modal berkewajiban melaksanakan tanggung jawab sosial perusahaan. Apabila perusahaan tidak melaksanakan kewajiban tersebut, maka akan dikenankan sanksi seperti yang diatur pada 134 yaitu berupa sanksi administratif dan sanksi-sanksi lainnya sesuai dengan ketentuan peraturan perundang-undangan yang berlaku.

Selain pemerintah yang merespon perkembangan CSR dengan mengakomodasinya melalui peraturan, sambutan baik kepada perusahaan yang terus meningkatkan kinerja sosialnya melalui CSR, dengan adanya penyelenggaraan Indonesian Sustainability Reporting Award (ISRA Award), Indonesian CSR Award (ICA Award) dan Global CSR Awards. Penghargaanpenghargaan tersebut dapat menjadi nilai tambah bagi citra perusahaan (Agrytasari, 2012, hlm. 3).

Menurut Alawi dan Azhar (2011) dalam Widiastuti (2014) dalam penelitiannya menemukan bahwa penghargaan semacam ini dapat meningkatkan pengungkapan CSR. Perusahaan akan termotivasi melaksanakan CSR jika lingkungan perusahaan itu sendiri (konsumen, investor dan stakeholders lainnya memberikan reward atas pelaksanaan CSR.

Menurut Yusuf, 2010 hlm. 101-102 dalam Mansur, 2012, hlm. 5, bahwa dalam Islam konsep CSR ini bukanlah sesuatu yang baru, beberapa ayat telah mengemukakan betapa pentingnya tanggung jawab sosial.

Menurut Widiawati (2012 hlm. 3), berkembangnya CSR dalam ekonomi Islam juga turut meningkatkan perhatian masyarakat terhadap lembaga atau institusi syariah. Hal tersebut dikarenakan adanya kebutuhan masyarakat untuk mengenal secara lebih dalam terhadap lembaga atau institusi syariah, semakin besar dari waktu ke waktu. Pasar modal sebagai lembaga dan profesi yang berkaitan dengan efek dalam hal ini adalah pasar modal syariah, berperan penting dalam meningkatkan pangsa pasar efek-efek syariah pada perusahaan-perusahaan yang ingin berpartisipasi dalam pasar modal syariah di Indonesia.

Salah satu produk pasar modal syariah di Indonesia saat ini adalah Jakarta Islamic Index (selanjutnya disebut sebagai JII). Saham-saham syariah yang masuk dalam JII merupakan saham yang sudah lolos melalui proses penyeleksian oleh Bursa Efek Indonesia (selanjutnya disebut sebagai BEI). 
Saham syariah yang menjadi konstituen JII terdiri dari 30 saham yang merupakan saham-saham syariah paling likuid dan memiliki kapitalisasi pasar yang besar. BEI melakukan review JII setiap 6 bulan, yang disesuaikan dengan periode penerbitan Daftar Efek Syariah (selanjutnya disebut sebagai DES) oleh Otoritas Jasa keuangan (OJK). Setelah dilakukan penyeleksian saham syariah oleh OJK yang dituangkan ke dalam DES, BEI melakukan proses seleksi lanjutan yang didasarkan kepada kinerja perdagangannya (www.idx.co.id).

Untuk itu, Othman et al. (2009) mengembangkan indeks pengungkapan yang relevan dengan hal-hal tersebut yang disebut dengan Islamic Social Reporting (ISR) Indeks. ISR pertama kali dikemukakan oleh Haniffa (2002) yang mengukurnya dalam 5 tema, yaitu (1) keuangan dan investasi, (2) produk, (3) karyawan, (4) sosial dan (5) lingkungan. Kemudian dikembangkan secara lebih ekstensif oleh Othman, et al. (2009) di Malaysia. Haniffa (2002) mengungkapkan bahwa adanya keterbatasan dalam pelaporan sosial konvensional sehingga ia mengemukakan kerangka konseptual Islamic Social Reporting (ISR) berdasarkan ketentuan syariah yang tidak hanya membantu pengambilan keputusan bagi pihak muslim melainkan juga untuk membantu perusahaan dalam melakukan pemenuhan kewajibannya terhadap Allah SWT dan masyarakat.

Indeks ISR merupakan tolak ukur pelaksanaan tanggung jawab sosial bagi institusi yang menjalankan operasionalnya sesuai dengan syariah yang berisi kompilasi poin-poin standar CSR yang ditetapkan oleh AAOIFI (Accounting and Auditing Organization for Islamic Financial Institutions) yang kemudian dikembangkan lebih lanjut oleh para peneliti mengenai poinpoin CSR yang seharusnya diungkapkan oleh suatu entitas Islam. Indeks ISR diyakini dapat menjadi pijakan awal dalam standar pengungkapan CSR yang sesuai dengan perspektif Islam (Maulida, et al. 2014, hlm. 2).

Berbagai penelitian yang terkait dengan faktor-faktor yang mempengaruhi pengungkapan tanggung jawab sosial perusahaan menunjukkan adanya keanekaragaman hasil. Hasil penelitian terdahulu yang dilakukan Othman, et al. (2009) pada perusahaan-perusahaan yang terdaftar dalam Bursa Malaysia menemukan bahwa faktor financial yaitu ukuran perusahaan dan profitabilitas secara signifikan mempengaruhi pengungkapan ISR. Sedangkan faktor non financial berupa ukuran dewan direksi muslim secara signifikan mempengaruhi tingkat pengungkapan ISR, akan tetapi jenis industri bukan faktor penting yang dapat mempengaruhi pengungkapan ISR secara signifikan.

Penelitian Raditya (2012), Nurman (2013), Putri (2014) dan juga menunjukkan hasil yang beraneka ragam. Ada beberapa faktor yang sama yang digunakan dalam penelitian mereka, namun menunjukkan hasil yang berbeda-beda. Faktor financial, ukuran perusahaan dan profitabilitas serta tipe industri, ukuran dewan komisaris dan status perusahaan sebagai faktor non financial, berpengaruh positif secara signifikan terhadap tingkat pengungkapan ISR pada penelitian Nurman (2013). Sedangkan pada penelitian Putri (2014) dan penelitian Raditya (2012), faktor financial 
profitabilitas tidak berpengaruh secara signifikan. Namun, untuk ukuran perusahaan, berpengaruh positif signifikan terhadap pengungkapan ISR. Adapun faktor non financial berupa tipe industri juga menunjukkan hasil yang tidak berpengaruh secara signifikan terhadap pengungkapan ISR.

Berdasarkan penjelasan di atas, dapat disimpulkan bahwa perusahaan yang terdaftar di JII, jika dia mampu mengungkapkan poin ISR nya secara penuh, maka akan mempunyai pengaruh dan dampak yang amat besar terhadap kelangsungan kehidupan lingkungan di sekitarnya, baik itu alam, masyarakat dan lain sebagainya. Hal ini dikarenakan perusahaan yang terdaftar dalam JII mempunyai kapitalisasi saham yang cukup besar. Selain itu juga, perusahaan yang terdaftar dalam JII, sudah bisa dipastikan bahwa perusahaan tersebut menjalankan aktivitas operasional yang tidak bertentangan dengan prinsip-prinsip syariah, sehingga perusahaan mempunyai kewajiban dan tanggung jawab untuk mengungkapkan CSR secara penuh yang pada penelitian ini diukur dengan indeks ISR.

Selain itu, berdasarkan penelitian-penelitian terdahulu tersebut, menunjukkan banyaknya faktor-faktor financial maupun non financial yang mempengaruhi pengungkapan Islamic Sosial Reporting (ISR) serta menunjukkan hasil yang beragam dan tidak konsisten. Maka dalam penelitian ini mencoba menguji kembali apakah faktor financial berupa size perusahaan, profitabilitas dan leverage, serta faktor non financial berupa jenis industri dan ukuran dewan komisaris adalah faktor-faktor yang dianggap memiliki pengaruh signifikan atau tidak terhadap tingkat pengungkapan Islamic Social Reporting (ISR) di Jakarta Islamic Index (JII) pada tahun 2012-2014.

\section{TELAAH LITERATUR}

\subsection{ISLAMIC SOCIAL REPORTING INDEX (ISR)}

Islamic Social Reporting adalah jawaban atas kebutuhan pengukuran tanggung jawab perusahaan yang berlandaskan syariat Islam. Dampak dari nilai dan filosofi Islam yang berbeda jauh dengan konsep CSR klasik, menjadikan perbedaan pula dalam praktik pengungkapan tanggung jawab sosial (Widiastuti, 2014, hlm. 29).

Islamic Social Reporting (ISR) merupakan perluasan dari pelaporan sosial yang tidak hanya berupa keinginan besar dari seluruh masyarakat terhadap peranan perusahaan dalam ekonomi melainkan berkaitan dengan perspektif spiritual (Haniffa, 2002). Islamic Social Reporting menekankan pada keadilan sosial terkait pelaporan mengenai lingkungan, hak minoritas dan karyawan. Selain keadilan sosial, hal penting lainnya dalam social reporting menurut perspektif Islam yaitu pemahaman konsep akuntabilitas dan konsep kepemilikan (Maali, et al. 2003). Seperti yang diungkapkan oleh Dewi (2012) bahwa ISR adalah perpanjangan pelaporan sosial yang meliputi tidak hanya harapan dewan pengurus atas pandangan masyarakat terhadap peran perusahaan dalam ekonomi, tetapi juga pemenuhan perspekif spiritual 
untuk pengguna laporan yang muslim serta bertujuan sebagai bentuk akuntabilitas kepada Allah SWT dan masyarakat.

Penelitian ini menggunakan kerangka Islamic Social Reporting dengan rujukan utama Haniffa (2002) yang dimodifikasi dengan poin-poin yang terdapat pada penelitian Othman dan Thani (2010), Othman et al. (2009), Fitria dan Hartanti (2010), Dewi (2012), Raditya (2012), Nurman (2013). Berikut keenam tema pengungkapan dalam Islamic Social Reporting yang digunakan dalam penelitian ini, antara lain Investasi dan Keuangan, Produk dan Jasa, Karyawan (Employees), Masyarakat (Community), Lingkungan Hidup (Environment), dan Tata Kelola Perusahaan (Corporate Governanance).

\section{METODOLOGI PENELITIAN}

\subsection{JENIS PENELITIAN}

Jenis penelitian yang digunakan dalam penelitian ini adalah jenis penelitian kuantitatif dengan menggunakan teknik analisis asosiatif. Dalam penelitian ini terdapat enam variabel yang akan diteliti hubungannya antara satu sama lain. Penelitian ini bertujuan untuk mengetahui hubungan variabel-variabel independen yang terdiri dari size perusahaan, profitabilitas, leverage, jenis industri dan ukuran dewan komisaris terhadap variabel tingkat pengungkapan pertanggung jawaban sosial yang diukur menggunakan indeks Islamic Social Reporting (ISR) pada perusahaan yang terdaftar dalam Jakarta Islamic Index (JII).

Data yang digunakan dalam penelitian ini berupa data kuantitatif yang diantaranya; total asset perusahaan sebagai proksi dari size perusahaan, tingkat profitabilitas diproksikan dengan presentase, tingkat leverage diproksikan dengan presentase, jenis industri diproksikan dengan memberi nilai dari klasifikasi perusahaan menurut usaha yang dijalankan, ukuran dewan komisaris berdasarkan jumlah komisaris yang dimiliki oleh perusahaan dan tingkat pengungkapan tanggung jawab sosial perusahaan yang diukur menggunakan Indeks Islamic Social Reporting (ISR) yang dinilai dengan metode content analysis.

\subsection{VARIABEL DEPENDEN: PENGUNGKAPAN ISLAMIC SOCIAL REPORTING (ISR)}

Pengungkapan tanggung jawab sosial dalam penelitian ini, menjadi variabel dependen yang akan menjadi sorotan utama pada pembahasan berikutnya. Pengungkapan tanggung jawab sosial pada perusahaan yang terdaftar di JII akan diproksikan dengan menggunakan Islamic Social Reporting Index berdasarkan poin-poin pengungkapan tanggung jawab sosial perusahaan yang dimodifikasi dalam penelitian Othman, et al. (2009), Dewi (2012), Raditya (2012) dan Nurman (2013) yang merupakan adaptasi dari indeks ISR yang dibuat oleh Hannifa, meliputi data yang diungkapkan oleh perusahaan berkaitan dengan aktivitas sosialnya mencakup tema lingkungan, energi, kesehatan dan keselamatan kerja, produk dan keterlibatan masyarakat umum. 
Nilai indeks tersebut diperoleh dengan menggunakan metode content analysis pada laporan tahunan perusahaan. Metode content analysis merupakan teknik analisis berbentuk dokumen dan teks yang berupaya menguantifikasi isi menurut kategori (indeks) yang sudah ditetapkan dengan cara sistematis dan dapat diulang-ulang (Widiawati, 2012, hlm. 54). Metode content analysis memungkinkan penulis untuk menganalisis berapa besar informasi dan mengidentifikasi secara sistematis terkait sifat-sifatnya, seperti ada atau tidaknya kata-kata, konsep, tema atau kalimat tertentu (Nurman, 2013, hlm. 35).

Dalam pengkodean indeks ISR dibagi menjadi enam tema besar yaitu investasi dan keuangan, produk dan jasa, tenaga kerja, sosial, lingkungan dan tata kelola organisasi. Selanjutnya tahap penilaian yang dilakukan adalah menggunakan scoring, dengan ketentuan:

1. Nilai 0 jika tidak ada pengungkapan terkait poin tersebut,

2. Nila 1 jika ada pengungkapan terkait poin tersebut.

Kemudian, apabila seluruh poin diungkapkan maka nilai maksimal yang dapat dicapai adalah sebesar $100 \%$ dengan jumlah seluruh poin pengungkapan ada 47 poin. Pengukuran variabel dependen ini merujuk pada peneliti sebelumnya yaitu Othman, et al. (2009), Dewi (2012), Raditya (2012) dan Nurman (2013) dengan beberapa modifikasi sesuai penelitian. Selanjutnya pengukuran indeks ISR setelah scoring dilakukan dengan rumus sebagai berikut:

Disclosure Level = Jumlah skor disclosure yang dipenuhi

Jumlah skor maksimum

\subsection{VARIABEL INDEPENDEN}

\subsubsection{Size Perusahaan}

Size perusahaan yang dimaksud adalah besar kecilnya perusahaan yang diukur dengan nilai total aset perusahaan. Total aset adalah total sumber daya yang dimiliki oleh perusahaan, sehingga perusahaan yang ukurannya besar pasti memerlukan total aset (sumber daya) yang banyak untuk menjalankan kegiatan usahanya (Dewi, 2012, hlm. 61). Maka, dalam penelitian ini size perusahaan diproksikan dengan total aset. Untuk menyamakan bentuk data variabel total aset yang diolah dengan variabel data yang lainnya, maka total aset akan dibentuk menjadi logaritma natural (ln).

\section{SIZE PERUSAHAAN = LN $($ TOTAL ASET $)$}

\subsubsection{Profitabilitas}

Profitabilitas adalah kemampuan suatu perusahaan untuk menghasilkan laba atau keuntungan (profit) dalam upaya meningkatkan nilai pemegang saham. Profitabilitas dapat diukur melalui beberapa jenis rasio antara lain: return on assets (ROA), return on equity (ROE), earning per share ataupun Net profit 
memprediksi variabel terikat (Santoso, 2012 hlm. 260). Jenis industri yang digunakan dalam penelitian ini, yaitu skor 1 untuk perusahaan yang termasuk dalam industri high profile dan skor 0 untuk perusahaan yang termasuk dalam industri low profile.

\subsubsection{Ukuran Dewan Komisaris}

Ukuran dewan komisaris yang digunakan dalam penelitian ini konsisten dengan penelitian yang dilakukan oleh Sembiring (2005) yaitu jumlah anggota dewan komisaris. Sebagaimana yang tertuang dalam Pasal 108 ayat 5 Undang-Undang No. 40 tahun 2007 tentang Perseroan Terbatas yang menyatakan bahwa perseroan yang kegiatan usahanya berkaitan dengan menghimpun dan/atau mengelola dana masyarakat, Perseroan yang menerbitkan surat pengakuan utang kepada masyarakat atau Perseroan terbuka wajib mempunyai paling sedikit 2 (dua) orang anggota Dewan Komisaris. Dalam peraturan BI No. 8/4/PBI/2006 pada pasal 4 ayat 1 juga diatur mengenai jumlah Dewan Komisaris paling kurang 3 (tiga) orang dan paling banyak sama dengan jumlah anggota Direksi (Agrytasari, 2012, hlm. $61)$.

\subsection{POPULASI DAN SAMPEL}

Berdasarkan hasil seleksi sampel yang sesuai dengan kriteria-kriteria yang telah ditentukan, maka rangkuman sampel yang digunakan dalam penelitian ini adalah sebagai berikut:

Tabel 2. Rangkuman Hasil Proses Pengambilan Sampel

\begin{tabular}{|c|c|c|}
\hline No. & Kriteria & $\begin{array}{c}\text { Jumlah } \\
\text { Perusahaan }\end{array}$ \\
\hline 1. & $\begin{array}{l}\text { Perusahaan masuk dalam daftar Jakarta Islamic Index } \\
\text { (JII) dan tercatat (listed) di Bursa Efek Indonesia } \\
\text { (BEI) selama periode penelitian yakni dalam kurun } \\
\text { waktu 2012-2014. }\end{array}$ & 34 \\
\hline 2. & $\begin{array}{l}\text { Eliminasi Perusahaan yang terdaftar dalam Jakarta } \\
\text { Islamic Index (JII), namun tidak konsisten masuk } \\
\text { selama periode penelitian yakni dalam kurun waktu } \\
\text { 2012-2014. }\end{array}$ & (15) \\
\hline 3. & $\begin{array}{l}\text { Eliminasi perusahaan yang tidak menggunakan satuan } \\
\text { mata uang rupiah dalam menerbitkan seluruh laporan } \\
\text { perusahaannya. }\end{array}$ & (3) \\
\hline 4. & $\begin{array}{l}\text { Eliminasi perusahaan yang tidak menerbitkan laporan } \\
\text { perusahaannya atau annual report pada website resmi } \\
\text { perusahaan atau BEI (keterbatasan data). }\end{array}$ & (0) \\
\hline & Total Perusahaan & 16 \\
\hline
\end{tabular}




\subsection{METODE ANALISIS DATA}

Analisis statistik digunakan untuk menguji kualitas data dan pengujian hipotesis. Rangkaian analisis statistik yang akan dilakukan dalam penelitian ini terdiri dari uji asumsi klasik dan uji hipotesis. Uji asumsi klasik ini terlebih dahulu peneliti lakukan sebelum melakukan pengujian hipotesis yaitu uji normalitas, uji multikolonearitas, uji heterokedestisitas dan uji autokorelasi yang bertujuan untuk mengetahui dan menguji kelayakan atas model regresi yang digunakan untuk penelitian ini. Pengujian ini juga dimaksudkan untuk memastikan bahwa di dalam model regresi yang digunakan tidak terdapat autokolerasi, multikolonearitas dan heteroskedestisitas serta untuk memastikan bahwa data yang dihasilkan berdistribusi normal.

Regresi linear berganda ditujukan untuk menentukan hubungan linear antar beberapa variabel bebas yang biasa disebut X1, X2, X3 dan seterusnya dengan variabel terikat yang disebut $Y$. Sehingga analisis regresi berganda ini bertujuan untuk melihat hubungan antara variabel size perusahaan, profitabilitas, leverage, jenis industri dan ukuran dewan komisaris terhadap variabel tingkat pengungkapan pertanggung jawaban sosial yang diukur menggunakan indeks Islamic Social Reporting (ISR) pada perusahaan yang terdaftar dalam Jakarta Islamic Index (JII). Model persamaannya adalah sebagai berikut:

\begin{tabular}{ll}
\hline ISRI $=\boldsymbol{\alpha}+\boldsymbol{\beta 1 S I Z E}+\boldsymbol{\beta 2 R O A}+\boldsymbol{\beta 3 L E V}+\boldsymbol{\beta 4 J I}+\boldsymbol{\beta 5 B O A R D}$ \\
\hline Keterangan : & $=$ Islamic Social Reporting Index \\
ISRI & $=$ Konstanta \\
$\alpha$ & $=$ Total Asset \\
SIZE & $=$ Profitabilitas \\
ROA & $=$ Leverage \\
LEV & $=$ Jenis Industri \\
JI & $=$ Ukuran Dewan Komisaris \\
BOARD & $=$ Koefisien Regresi \\
$\beta 1, \beta 2, \beta 3, \beta 4, \beta 5$ & $=$ Error (Pengganggu) \\
$\mathrm{e}$ &
\end{tabular}

\section{HASIL DAN ANALISA}

\subsection{TINGKAT PENGUNGKAPAN ISR PERUSAHAAN BERDASARKAN TOTAL POIN YANG DIUNGKAPKAN}

Dalam penelitian ini, indikator pengungkapan tanggung jawab sosial perusahaan berdasarkan indeks Islamic Social Reporting (ISR) terdiri dari 
enam tema, yaitu investasi dan keuangan, produk dan jasa, tenaga kerja, sosial, lingkungan, dan tata kelola organisasi yang terdiri dari 47 poin pengungkapan. Berikut gambaran tingkat pengungkapan ISR perusahaan yang terdaftar dalam JII selama tahun 2012-2014.

Tabel 3. Deskripsi Pengungkapan Islamic Social Reporting Pada Perusahaan yang Terdaftar di JII

\begin{tabular}{|c|c|c|c|c|c|c|c|c|c|}
\hline \multirow{3}{*}{ No } & \multirow{3}{*}{$\begin{array}{c}\text { Nama } \\
\text { Perusa } \\
\text { haan }\end{array}$} & \multicolumn{6}{|c|}{ Jumlah Poin \& Presentase yang Diungkapkan } & \multirow{3}{*}{$\begin{array}{c}\text { Rata- } \\
\text { rata per } \\
\text { Tahun }\end{array}$} & \multirow{3}{*}{$\begin{array}{l}\text { Rata- } \\
\text { Rata } \\
\text { Presenta } \\
\text { se } \\
\text { Pengung } \\
\text { kapan } \\
\text { ISR }(\%)\end{array}$} \\
\hline & & \multicolumn{2}{|c|}{2012} & \multicolumn{2}{|c|}{2013} & \multicolumn{2}{|c|}{2014} & & \\
\hline & & Jumlah & $\%$ & $\begin{array}{c}\mathrm{Ju} \\
\mathrm{mla} \\
\mathrm{h}\end{array}$ & $\%$ & $\begin{array}{c}\text { Juml } \\
\text { ah }\end{array}$ & $\%$ & & \\
\hline 1 & PTBA & 30 & 63,83 & 30 & 63,83 & 30 & 63,83 & 30,00 & $63,83 \%$ \\
\hline 2 & TLKM & 28 & 59,57 & 28 & 59,57 & 31 & 65,96 & 29,00 & $61,70 \%$ \\
\hline 3 & ICBP & 26 & 55,32 & 29 & 61,70 & 29 & 61,70 & 28,00 & $59,57 \%$ \\
\hline 4 & ASII & 28 & 59,57 & 27 & 57,45 & 27 & 57,45 & 27,33 & $58,16 \%$ \\
\hline 5 & INDF & 28 & 59,57 & 27 & 57,45 & 27 & 57,45 & 27,33 & $58,16 \%$ \\
\hline 6 & INTP & 26 & 55,32 & 27 & 57,45 & 28 & 59,57 & 27,00 & $57,45 \%$ \\
\hline 7 & KLBF & 26 & 55,32 & 27 & 57,45 & 28 & 59,57 & 27,00 & $57,45 \%$ \\
\hline 8 & UNVR & 27 & 57,45 & 27 & 57,45 & 27 & 57,45 & 27,00 & $57,45 \%$ \\
\hline 9 & AALI & 28 & 59,57 & 26 & 55,32 & 26 & 55,32 & 26,67 & $56,74 \%$ \\
\hline 10 & UNTR & 26 & 55,32 & 27 & 57,45 & 27 & 57,45 & 26,67 & $56,74 \%$ \\
\hline 11 & LSIP & 26 & 55,32 & 26 & 55,32 & 27 & 57,45 & 26,33 & $56,03 \%$ \\
\hline 12 & AKRA & 27 & 57,45 & 27 & 57,45 & 24 & 51,06 & 26,00 & $55,32 \%$ \\
\hline 13 & SMGR & 26 & 55,32 & 25 & 53,19 & 27 & 57,45 & 26,00 & $55,32 \%$ \\
\hline 14 & LPKR & 21 & 44,68 & 22 & 46,81 & 23 & 48,94 & 22,00 & $46,81 \%$ \\
\hline 15 & CPIN & 22 & 46,81 & 21 & 44,68 & 21 & 44,68 & 21,33 & $45,39 \%$ \\
\hline 16 & ASRI & 19 & 40,43 & 19 & 40,43 & 22 & 46,81 & 20,00 & $42,55 \%$ \\
\hline \multicolumn{2}{|c|}{ Total } & 414 & \multirow[b]{2}{*}{55,05} & 415 & \multirow[b]{2}{*}{55,19} & 424 & \multirow[b]{2}{*}{56,38} & & \multirow[b]{2}{*}{$55,54 \%$} \\
\hline \multicolumn{2}{|c|}{$\begin{array}{l}\text { Rata-rata per } \\
\text { Perusahaan }\end{array}$} & 25,88 & & $\begin{array}{l}25 \\
94\end{array}$ & & 26,50 & & & \\
\hline
\end{tabular}

Sumber: Data Sekunder yang Diolah, 2015

Berdasarkan presentase ISR dalam tabel di atas, peringkat perusahaan secara berurutan dimulai dari yang tertinggi hingga terendah berdasarkan tingkat indeks ISR-nya yaitu, PTBA, TLKM, ICBP, ASII, INDF, INTP, KLBF, UNVR, AALI, UNTR, LSIP, AKRA, SMGR, LPKR, CPIN, dan ASRI. Jumlah poin yang diungkapkan oleh perusahaan setiap tahunnya 
sangat bervariasi ada yang mengalami kenaikan setiap tahunnya, tetap ataupun menurun.

Jika dilihat dari total poin yang diungkapkan seluruh perusahaan setiap tahunnya, terlihat bahwa ada peningkatan poin pengungkapan ISR setiap tahunnya, yaitu 414 poin pengungkapan pada tahun 2012 dengan ratarata per perusahaan 25 poin dan presentasenya mencapai $55 \%$, kemudian bertambah satu poin di tahun 2012, yakni menjadi 415 poin pengungkapan, kemudian peningkatan yang cukup signifikan pada tahun 2014 bertambah 9 poin yakni menjadi sebesar 424 poin pengungkapan. Jika dipresentasekan, kenaikan pengungkapan dari tahun 2012 ke tahun 2013 sebesar 0,14\% dan kenaikan dari tahun 2013 ke tahun 2014 adalah sebesar 1,19\%.

Perusahaan dengan rata-rata pengungkapan poin terbanyak diraih oleh PT Bukit Asam (Persero) Tbk (PTBA) dengan poin rata-rata sebanyak 30 poin dari total 47 poin pengungkapan secara keseluruhan. Hal tersebut berarti PT Bukit Asam (Persero) Tbk telah melakukan pengungkapan yang sesuai dengan indeks ISR, yakni sebesar $63,83 \%$. Pengungkapan tanggung jawab sosial tersebut pastinya diikuti dengan pelaksanaan tanggung jawab sosial yang sebenarnya.

Selain itu pengungkapan ISR setiap tahun oleh PT Bukit Asam (Persero) Tbk, menunjukkan angka yang konsisten setiap tahunnya. PT Bukit Asam (Persero) Tbk juga mempunyai program CSR yang cukup beragam, bahkan pengelolaannya telah mempunyai manajemen yang terstruktur. Hal inilah yang membuat PT Bukit Asam (Persero) Tbk juga mendapatkan anugerah tertinggi Program Penilaian Peringkat Kinerja Perusahaan dalam Pengelolaan Lingkungan Hidup (PROPER) Emas dari Kementerian Lingkungan Hidup pada tanggal 03 Desember 2014.

Kemudian perusahaan selanjutnya dengan rata-rata pengungkapan poin terbanyak diraih oleh PT Telekomunikasi Indonesia (Persero) Tbk (TLKM). PT Telekomunikasi Indonesia (Persero) Tbk berhasil mengungkapkan poin ISR rata-rata setiap tahunnya sebanyak 29 poin dari total 47 poin pengungkapan keseluruhan dengan presentase $61,70 \%$. Selain itu poin pengungkapan tertinggi dari keseluruhan perusahaan ada pada PT Telekomunikasi Indonesia (Persero) Tbk yakni sebesar 31 poin pada tahun 2014. Hal ini menjadi prestasi tersendiri bagi PT Telekomunikasi Indonesia (Persero) Tbk yang telah melakukan pengungkapan sesuai dengan indeks ISR.

Walaupun pengungkapannya belum konsisten setiap tahunnya, akan tetapi ada peningkatan pengungkapan sebanyak 3 poin dari tahun 2013 ke tahun 2014. PT Telekomunikasi Indonesia juga berhasil meraih kategori Grand Platinum pada Anugerah Indonesia CSR Awards (ICA) 2014 tentang tanggung jawab sosial perusahaan yang berbasis ISO 26000 yang diselenggarakan oleh Corporate Forum for Community Development (CFCD).

Kedua perusahaan tersebut sama-sama termasuk dalam salah satu perusahaan BUMN, yang dalam penelitian ini menduga bahwa besarnya poin pengungkapan ISR yang diungkapkan sebagai bentuk tanggung jawab sosial 
perusahaan terhadap masyarakat dan lingkungan di sekitarnya, karena adanya peraturan pemerintah No. 47 Tahun 2012 tentang tanggung jawab sosial dan lingkungan perseroan terbatas, yang merupakan peraturan pelaksana dari ketentuan pasal 74 UU No. 40 Tahun 2007 tentang Perseoan Terbatas. Sehingga PTBA dan TLKM harus patuh terhadap adanya regulasi tersebut.

Adapun perusahaan dengan pengungkapan poin ISR terendah ada pada PT Alam Sutera Realty Tbk (ASRI) yang hanya berhasil mengungkapkan poin rata-rata selama tiga tahun terakhir sebanyak 20 poin dengan presentase $42,55 \%$. Selanjutnya disusul peringkat pengungkapan ISR terendah kedua oleh PT Charoen Pokphan Indonesia Tbk (CPIN) dengan rata-rata poin pengungkapan selama tiga tahun sebanyak 21 poin dengan presentase sebesar 45,39\%.

Grafik 1. Tingkat Pengungkapan ISR Perusahaan yang Terdaftar di JII Tahun 2012-2014

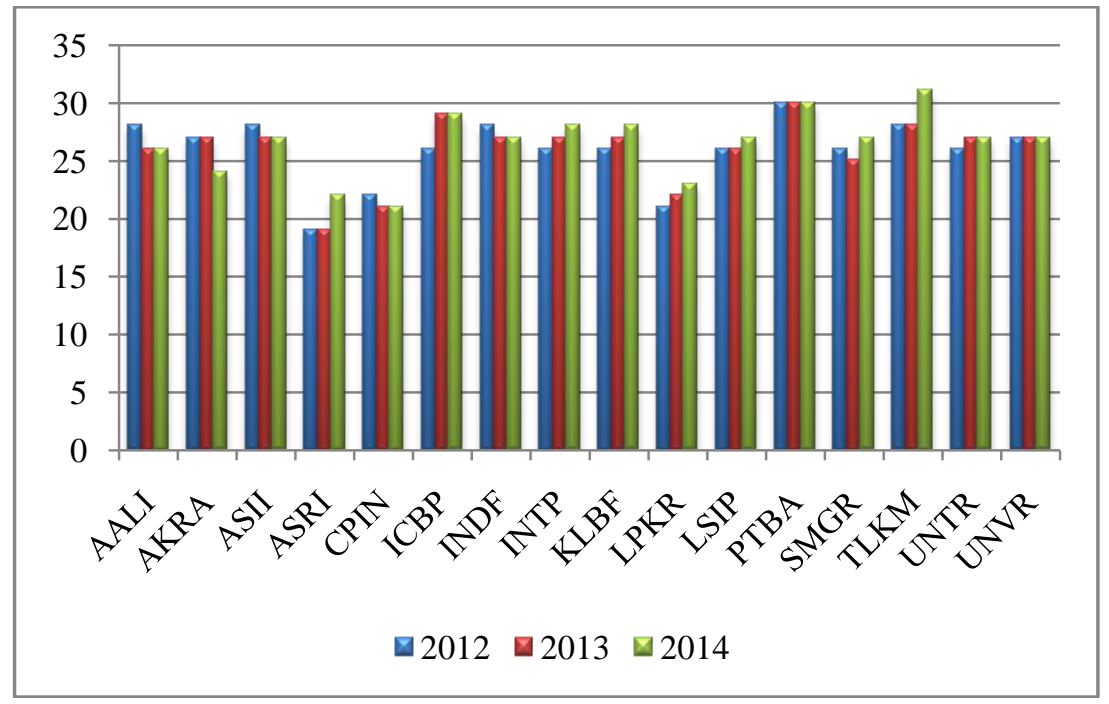

Sumber : Data Sekunder yang Diolah, 2015

Pada grafik 1 di atas terlihat 2 perusahaan konsisten dalam mengungkapkan CSRnya yaitu PTBA (PT Bukit Asam (Persero) Tbk) dan UNVR (PT Unilever Indonesia Tbk) dengan nilai masing-masing 30 $(63,83 \%)$ dan $27(57,45 \%)$ setiap tahunnya. Sedangkan 14 perusahaan lainnya walaupun tidak konsisten, namun mengalami perubahan postif (naik) ataupun perubahan negatif (turun). Perusahaan yang mengalami perubahan positif (naik) sebanyak 8 perusahaan diantaranya ASRI, ICBP, INTP, KLBF, LPKR, LSIP, TLKM, dan UNTR. Setelah dilakukan pengamatan lebih jauh, kedelapan perusahaan tersebut mengalami perubahan hanya pada tema pengungkapan karyawan, masyarakat dan lingkungan hidup. Walaupun tidak sepenuhnya poin yang berubah adalah poin pengungkapan yang sama. Ada juga beberapa poin yang diungkapkan pada tahun 2012, namun pada tahun 
2013 atau tahun 2014 poin tersebut tidak diungkapkan. Ataupun hal sebaliknya yang terjadi.

Selain itu dari kedelapan perusahaan yang mengalami perubahan positif tersebut, perubahan peningkatan tertinggi terjadi pada perusahaan ICBP dan TLKM. Pada tahun 2013 ICBP mengalami peningkatan pengungkapan sebesar 3 poin atau jika dipresentasekan yaitu sebesar 6,38\%, dimana skor sebelumnya yang hanya 26 poin. Sedangkan, TLKM pada tahun 2014 juga mengalami peningkatan pengungkapan sebesar 3 poin, dari skor sebelumnya 28 poin menjadi 31 poin atau sebesar $6,39 \%$ presentase kenaikan pengungkapannya.

Sedangkan perusahaan yang mengalami perubahan negatif (turun) secara berturut-turut selama 3 tahun sebanyak 6 perusahaan, diantaranya AALI, AKRA, ASII, CPIN, INDF, dan SMGR. Untuk SMGR, poin pengungkapan pada tahun 2013 mengalami penurunan sebesar 1 poin dari poin sebelumnya yang berjumlah 26 poin pengungkapan. Namun, pada tahun 2014 mengalami kenaikan lagi sebesar satu poin menjadi 27 poin pengungkapan. Perubahan poin kenaikan ini terjadi pada tema tata kelola perusahaan, yaitu pada poin pengungkapan mengenai perkara hukum dan kebijakan anti korupsi.

Dari keenam perusahaan tersebut, penurunan pengungkapan tertinggi terjadi pada perusahaan AKRA. Pada tahun 2012 dan 2013, poin pengungkapan perusahaan AKRA sama yaitu berada pada poin 27 dengan presentase 57,45\%. Namun, pada tahun 2014 poin pengungkapannya mengalami penurunan yang cukup besar yaitu sebnayak 3 poin, sehingga menjadi hanya 24 poin pengungkapan saja dengan presentase $51,06 \%$. Penurunan poin ini terjadi pada tema karyawan serta tema keuangan dan investasi.

Sebagai tambahan informasi lain, perlu diketahui bahwa penelitian ini menggunakan poin-poin pengujian yang telah disesuaikan berdasarkan karakteristik perusahaan. Hal ini dilakukan untuk meminimalisir kesenjangan, karena standar yang ditetapkan AAOIFI dibentuk untuk berbagai macam industri. Meskipun demikian, tetap ada beberapa poin yang tidak diungkapkan sama sekali seperti zakat, kegiatan yang mengandung gharar, tempat ibadah yang memadai, jam kerja karyawan, wakaf, qardhul hasan, pengungkapan praktik monopoli usaha, praktik menimbun bahan kebutuhan pokok, dan praktik manipulasi harga.

Penjelasan pengungkapan tanggung jawab sosial perusahaan yang terdaftar di JII berdasarkan 6 tema besar, menyimpulkan bahwa tema produk dan jasa memperoleh tingkat tertinggi. Kemudian disusul oleh tema masyarakat dengan selisih $17 \%$. Peringkat selanjutnya diraih oleh tema lingkungan sebesar 59,17\%. Sedangkan, urutan tiga terendah berurutan diperoleh tema keuangan dan investasi $(55,83 \%)$, tema tata kelola perusahaan $(43,28 \%)$, dan tema karyawan (40,38\%). Grafik 4.8 di bawah ini menunjukkan perbedaan skor ISR setiap tema tersebut.

Grafik 2. Peringkat Pengungkapan ISR Berdasarkan Tema 


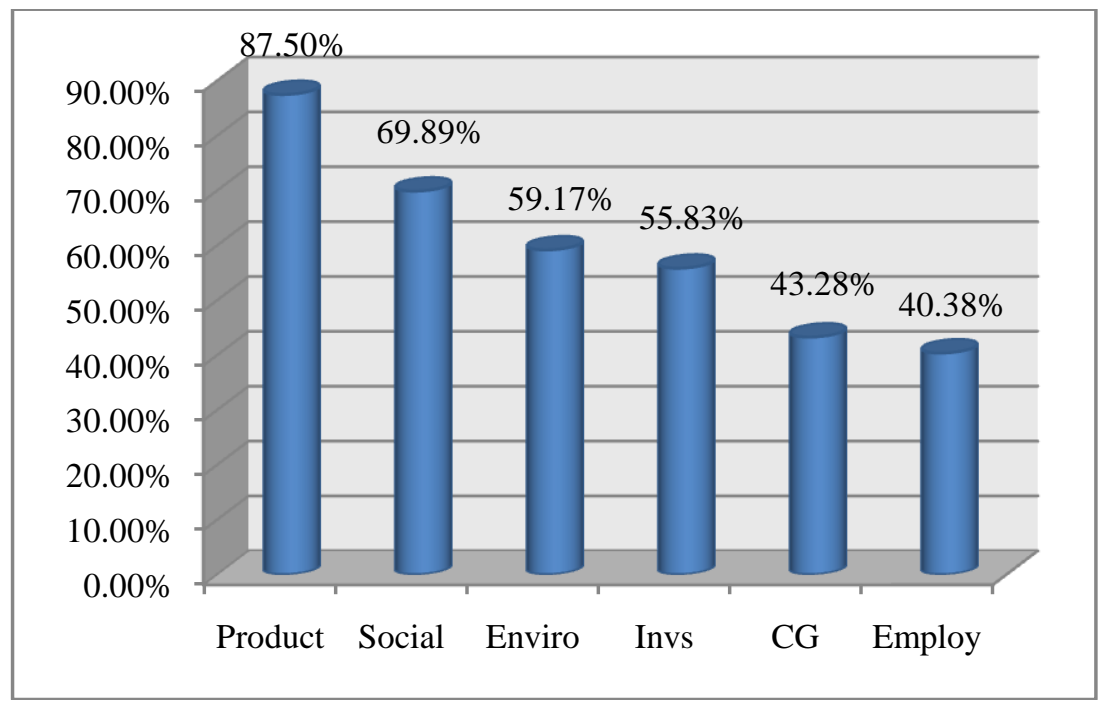

Sumber : Data Sekunder yang Diolah, 2015

Grafik di atas menunjukkan tingkat pengungkapan ISR terbesar berdasarkan tema yang paling banyak adalah tema produk dan jasa. Salah satu alasan tingginya pengungkapan tema ini, karena tingginya tingkat persaingan perusahaan yang mengharuskan perusahaan berlomba-lomba untuk memberikan pelayanan terbaiknya kepada pelanggan. Bukan itu saja, kehalalan, mutu dan kualitas produk pun menjadi nilai bagi sebuah perusahaan. Sedangkan, tema terendah yang diungkapkan oleh perusahaan yang terdaftar di JII adalah tema karyawan. Salah satu penyebab rendahnya tema pengungkpan karyawan ini adalah dikarenakan kurangnya tingkat kereligiusan dalam hal beragama di masing-masing perusahaan, sehingga pengungkapannya kurang sesuai dengan ISR karena pengungkapan yang mengandung unsur syariah masih sedikit yang melakukannya. Hal ini konsisten dengan penelitian Dewi (2012).

\subsection{ANALISIS STATISTIK DAN PENGUJIAN HIPOTESIS}

\subsubsection{Analisis Uji Asumsi Klasik}

Model regresi linier berganda (multiple regression) dapat disebut sebagai model yang baik jika model tersebut memenuhi kriteria BLUE (Best Linier Unbiased Estimator). BLUE dapat dicapai bila memenuhi asumsi klasik. Hal tersebut dapat dibuktikan dengan beberapa pengujian, diantaranya normalitas, autokorelasi, multikolonearitas, dan heterokedastisitas. (Setyadharma, 2010 dalam Widiastuti, 2014). Hasil uji asumsi klasik terhadap data penelitian diringkaskan sebagai berikut.

Tabel 4. Hasil Uji Asumsi Klasik

\begin{tabular}{|c|c|c|}
\hline Variabel Independen & Koefisien & $\begin{array}{l}t \text { - } \\
\text { statistik }\end{array}$ \\
\hline
\end{tabular}




\begin{tabular}{lllll}
\hline Intercept & -0.125 & -0.803 & 0.426 & \\
SIZE & 0.005 & 0.895 & 0.376 & 2.915 \\
ROA & 0.052 & 1.500 & 0.141 & 1.098 \\
LEV & -0.005 & -0.819 & 0.417 & 1.442 \\
JI & 0.012 & 1.032 & 0.308 & 1.936 \\
BOARD & -0.002 & -0.599 & 0.552 & 2.263 \\
Durbin-Watson & 1.844 & & & \\
Skewness & $0.495^{*}$ & & & \\
Kurtosis & $0.464^{* *}$ & & & \\
& & & & \\
Notes: & & & & \\
Dependent & & & & \\
Unstandardized Residual & & & & \\
Standard error Skewness* & 0.343 & & \\
Standard error Kurtosis** & 0.674 & & \\
\hline
\end{tabular}

Sumber : Data Sekunder Diolah, 2015

Berdasarkan keempat hasil uji asumsi klasik di atas, maka model ini dinyatakan memenuhi kriteria BLUE dan waktu dianggap tidak memiliki pengaruh. Sehingga dapat disimpulkan, bahwa penyelesaiannya bisa menggunakan uji regresi linear berganda menggunakan alat analisis SPSS vs. 18.0.

\subsubsection{Hasil Uji Regresi Linear Berganda}

Pada tahap ini akan dilakukan analisis regresi linear berganda dengan bantuan SPSS vs. 18. Berdasarkan output analisis yang dihasilkan, akan dilakukan beberapa pengujian yang terdiri dari model regresi linear berganda ISRI, nilai $\mathrm{R}^{2}$, uji signifikan simultan (Uji F), dan signifikan parsial (Uji t). Sebagai langkah awal, berikut ini hasil regresi SPSS vs. 18 yang diperoleh dalam tabel 4.11 di bawah ini.

Tabel 5. Hasil Analisis Regresi Linear Berganda

\begin{tabular}{lllll}
\hline Variabel Independen & $\begin{array}{l}\text { Sifat } \\
\text { Hubungan }\end{array}$ & Koefisien & t-statistik & p-value \\
\hline Intercept & & -0.031 & -0.119 & 0.906 \\
SIZE & + & 0.020 & 2.284 & 0.027 \\
ROA & - & -0.368 & -6.397 & 0.000 \\
LEV & - & $-0,037$ & -3.869 & 0.000 \\
JI & + & 0.151 & 7.811 & 0.000 \\
BOARD & - & -0.011 & -2.475 & 0.017 \\
F-value & 24.397 & & & \\
Sign. F (p-value $)$ & 0.000 & & & \\
R & 0.862 & & & \\
$\mathrm{R}^{2}$ & 0.744 & & & \\
Adjusted R & 0.713 & & & \\
\hline
\end{tabular}


Tabel 5 di atas menggambarkan koefisien variabel independen terhadap variabel dependen yang dirangkai menjadi persamaan model regresi berganda sebagai berikut.

\begin{tabular}{ll}
$\mathrm{ISR}$ & $=\begin{array}{l}-0.031+0.020 \text { SIZE }-0.368 \mathrm{ROA}-0.037 \mathrm{LEV}+0.151 \mathrm{JI}-0.011 \\
\mathrm{I} \\
\mathrm{BOARD}+\mathrm{e}\end{array}$ \\
\hline
\end{tabular}

Model regresi di atas menunjukkan variabel SIZE dan JI memiliki hubungan yang positif dengan ISRI. SIZE (total asset) berpengaruh signifikan dengan arah koefisien positif 0,020 terhadap tingkat ISR, yang berarti setiap peningkatan $1 \%$ akan menyebabkan peningkatan nilai indeks ISR perusahaan sebesar 0,020\%. Begitu pula dengan jenis industri yang berpengaruh signifikan dengan arah koefisien positif 0,151, yang berarti setiap peningkatan $1 \%$ akan menyebabkan peningkatan nilai indeks ISR perusahaan sebesar $0,151 \%$. Artinya, semakin tinggi nilai SIZE dan JI pada perusahaan, maka tingkat pengungkapan ISR akan semakin tinggi.

Sementara itu, terdapat pula variabel independen yang memiliki hubungan negatif dengan ISRI yaitu ROA, LEV, dan BOARD. Profitabilitas (ROA) berpengaruh signifikan dengan arah koefisien negatif 0,368 terhadap tingkat ISR, yang berarti setiap peningkatan $1 \%$ akan menyebabkan penurunan nilai indeks ISR perusahaan sebesar $0,368 \%$. Sama halnya dengan ROA, Leverage (LEV) berpengaruh signifikan dengan arah koefisien negatif 0,037 terhadap tingkat ISR, yang berarti setiap peningkatan $1 \%$ akan menyebabkan penurunan nilai indeks ISR perusahaan sebesar 0,037\%.

Selain itu, Ukuran Dewan Komisaris (BOARD) juga memiliki hubungan negatif dengan ISRI, Ukuran Dewan Komisaris (BOARD) berpengaruh signifikan dengan arah koefisien negatif 0,011 terhadap tingkat ISR, yang berarti setiap peningkatan $1 \%$ akan menyebabkan penurunan nilai indeks ISR perusahaan sebesar $0,011 \%$. Artinya jika nilai ROA, LEV, dan BOARD semakin tinggi justru akan membuat tingkat pengungkapan ISR semakin rendah. Hasil pengujian ini menolak dugaan awal ROA, LEV, dan, BOARD memiliki hubungan positif terhadap tingkat pengungkapan ISR perusahaan di JII.

Melalui $\mathrm{R}^{2}$ dapat terlihat seberapa besar kemampuan variabel independen menjelaskan variabel dependen. Semakin besar nilai $\mathrm{R}^{2}$ maka semakin kecil pula tingkat error dalam persamaan regresi. Berdasarkan hasil pengujian yang ada dalam tabel $4.11, \mathrm{R}^{2}$ yang diperoleh sebesar $74,4 \%$. Artinya seluruh variabel independen yang digunakan dalam persamaan regresi ini memiliki $74,4 \%$ dalam menjelaskan luas ISRI perusahaan yang terdaftar di JII. Sedangkan sisanya 25,6\% dipengaruhi oleh variabel lain yang tidak diteliti dalam penelitian ini.

Seperti yang telah dibahas sebelumnya, uji $\mathrm{F}$ ini berfungsi untuk mengetahui signifikansi keseluruhan variabel independen terhadap variabel dependen. Berdasarkan tabel 4.11 menunjukkan bahwa uji statistik F hitung sebesar 24,397. Sedangkan, derajat kebebasan pembilang $\mathrm{k}-1=5-1=4$, serta derajat bebas penyebut $(n-k)=(48-5)=43$. Maka akan diperoleh nilai F tabel sebesar 2,43. P-value yang diperoleh 0,000 lebih kecil dari $\alpha=0,05$. Sehingga, kesimpulan yang diperoleh $\mathrm{H}_{\mathrm{f}}$ ditolak, secara otomatis $\mathrm{H}_{\mathrm{f}}$ 
diterima. Hal tersebut terlihat dari $\mathrm{F}$ hitung $>\mathrm{F}$ tabel dan nilai $p$-value $<0,05$. Dengan demikian, terbukti bahwa SIZE, ROA, LEV, JI, dan BOARD secara simultan signifikan berpengaruh secara positif terhadap tingkat pengungkapan ISRI.

\subsection{PEMBAHASAN HASIL PENGUJIAN HIPOTESIS}

Ringkasan atas hasil pengujian tingkat signifikan msaing-masing variabel independen dapat dilihat dalam tabel 4.12 berikut ini.

Tabel 6. Ringkasan Hasil Uji Signifikan Parsial

\begin{tabular}{cccccc}
\hline & SIZE & ROA & LEV & JI & BOARD \\
\hline ISRI & 0,027 & 0,000 & 0,000 & 0,000 & 0,017 \\
\hline \multicolumn{5}{c}{ Sumber : Data Sekunder yang Diolah, 2015 }
\end{tabular}

Pembahasan atas hasil uji hipotesis di atas akan dijabarkan dalam ulasan berikut ini berdasarkan pengaruh masing-masing variabel independen terhadap variabel dependen.

\subsubsection{Size Perusahaan Terhadap Tingkat Pengungkapan Islamic Social Reporting (ISR)}

Sebagaimana yang telah dijelaskan sebelumnya, Size perusahaan dalam penelitian ini diproksikan nilai total asset perusahaan yang dibentuk menjadi logaritma natural (ln) untuk menyamakan bentuk data variabel total aset. Size berpengaruh signifikan dengan arah koefisien positif $(0,020)$ terhadap tingkat ISR, yang berarti setiap peningkatan nilai size perusahaan sebesar $1 \%$ akan menyebabkan peningkatan nilai indeks ISR perusahaan sebesar $0,020 \%$. Signifikansi Size mencapai 0,027 di bawah taraf nyata 0,05.

Hasil penelitian mengenai size perusahaan yang mempunyai pengaruh positif yang signifikan konsisten dengan hasil penelitian-penelitian sebelumnya Othman, et al., (2009), Raditya (2012), dan Dewi (2012) yang dapat membuktikan bahwa size perusahaan berpengaruh signifikan terhadap pengungkapan Islamic Social Reporting.

Berdasarkan hasil penelitian ini dapat di buktikan bahwa perusahaan yang berukuran besar cenderung memiliki pengungkapan informasi yang lebih tinggi dibandingkan dengan perusahaan yang berukuran lebih kecil karena dengan ukuran perusahaan yang besar, maka tanggung jawab perusahaan akan kesejahteraan masyarakat dan lingkungan sekitarnya akan semakin diperhatikan oleh para investor muslim dan para pengguna laporan muslim lainnya. Selain itu perusahaan yang berukuran besar dianggap lebih mempunyai kemampuan untuk memberikan pengungkapan yang lebih luas. Hubungan lainnya antara ukuran perusahaan dengan tingkat pengungkapan adalah semakin besar suatu perusahaan maka semakin banyak analisis di bursa saham yang tertarik untuk menganalisa kinerja perusahaan tersebut, sehingga dibutuhkan pengungkapan yang lebih banyak.

\subsubsection{Profitabilitas Terhadap Tingkat Pengungkapan Islamic Social Reporting (ISR)}


Profitabilitas dalam penelitian ini diukur menggunakan return on assets (ROA). Rasio ini dihitung dengan cara membagi nilai laba bersih setelah pajak dengan total asset. Hasibuan (2001) dalam Agrytasari (2012) menyatakan bahwa berdasarkan teori legitimasi, salah satu argumen dalam hubungan antara profitabilitas dan tingkat pengungkapan tanggung jawab sosial adalah ketika perusahaan memiliki laba yang tinggi, perusahaan tidak perlu melaporkan hal-hal yang mengganggu informasi tentang suksesnya keuangan mereka. Sebaliknya, saat profitabilitas mereka rendah, perusahaan akan menampilkan pencapaian lain selain kinerja keuangan salah satunya pengungkapan CSR. Hal itu dilakukan guna memperbaiki legitimasi yang diberikan dan menarik perhatian investor.

Hasil uji t, diperoleh angka $-6,397$ dengan derajat kebebasan $\mathrm{n}-\mathrm{k}=$ $48-5=43$. Maka diperoleh nilai $\mathrm{t}$ hitung 1,681 , nilai $\mathrm{t}$ hitung $<\mathrm{t}$ tabel. Sedangkan, $p$-value yang diperoleh $0,000<0,05$. Sehingga dapat disimpulkan $\mathrm{H}_{\mathrm{b}}$ ditolak, secara otomatis $\mathrm{H}_{\mathrm{b}}$ diterima. Sehingga Profitabilitas (ROA) terbukti signifikan berpengaruh secara positif terhadap tingkat pengungkapan ISRI. Sedangkan untuk nilai koefisien, profitabilitas mempunyai nilai koefisien negatif yaitu sebesar $-0,368$, yang berarti setiap peningkatan nilai ROA sebesar $1 \%$ akan menyebabkan penurunan nilai indeks ISR perusahaan sebesar $0,368 \%$.

Hasil pengaruh yang signifikan ini konsisten dengan hasil penelitianpenelitian sebelumnya yaitu Othman, et al. (2009) dan Raditya (2012) yang membuktikan bahwa profitabilitas perusahaan mempunyai pengaruh yang signifikan terhadap tingkat pengungkapan Islamic Social Reporting. Selain itu hasil penelitian ini juga konsisten dengan hasil penelitian Haniffa dan Cooke (2005) yang dalam penelitiannya mendapatkan hasil bahwa profitabilitas berpengaruh positif yang signifikan terhadap pengungkapan tanggung jawab sosial.

Berdasarkan hasil penelitian ini, hipotesis yang dapat dibuktikan yaitu perusahaan dengan profitabilitas yang tinggi akan cenderung lebih rendah dalam melakukan pengungkapan ISR. Hal ini dikarenakan ketika perusahaan memiliki laba yang besar, mereka menganggap tidak perlu melaporkan halhal apa saja yang menjadi kesuksesan pencapaian laba mereka. Karena ketika mereka mengungkapkan hal tersebut, otomatis mereka juga harus mengungkapkan kinerja CSR yang sesuai. Sebaliknya, saat profitabilitas mereka rendah, perusahaan akan menampilkan pencapaian lain selain kinerja keuangan, salah satunya pengungkapan CSR. Hal itu dilakukan guna memperbaiki legitimasi yang diberikan dan menarik perhatian investor. Hal ini sejalan dengan penelitian Hasibuan (2001) yang dikutip Agrytasari (2012).

\subsubsection{Leverage Terhadap Tingkat Pengungkapan Islamic Social Reporting}

Dalam penelitian ini, leverage yang diproksikan dengan rasio hutang terhadap modal menunjukkan hubungan positif terhdap pengungkapan ISR. Hasil uji t, diperoleh angka $-3,869$ dengan derajat kebebasan $\mathrm{n}-\mathrm{k}=48-5=$ 43. Maka diperoleh nilai t hitung 1,681, nilai t hitung < t tabel. Sedangkan, $p$ - 
value yang diperoleh $0,000<0,05$. Sehingga dapat disimpulkan $\mathrm{H} 0_{c}$ ditolak, secara otomatis secara otomatis $\mathrm{H}_{\mathrm{c}}$ diterima. Leverage terbukti signifikan berpengaruh secara positif terhadap tingkat pengungkapan ISRI. Sedangkan untuk nilai koefisiennya, variabel leverage mempunyai nilai koefisien negatif sebesar -0,037, yang berarti apabila variabel leverage berpengaruh signifikan pada pengungkapan indeks ISR, maka setiap peningkatan $1 \%$ leverage akan menyebabkan penurunan sebesar 0,037 pengungkapan ISR.

Hasil penelitian ini tidak sejalan dengan penelitian sebelumnya yang dilakukan oleh Cahya (2010) dan Sembiring (2005), yang menemukan bahwa leverage tidak memiliki pengaruh yang signifikan terhadap pengungkapan ISR. Namun, berbeda dengan hasil penelitian yang dilakukan Robert (1992) dalam Sembiring (2005). Ia menemukan adanya hubungan yang positif antara kedua variabel tersebut.

Berdasarkan hasil penelitian ini, hipotesis yang dapat dibuktikan yaitu bahwa perusahaan dengan leverage yang tinggi, akan cenderung lebih rendah dalam melakukan pengungkapan ISR. Hal ini mungkin disebabkan karena perusahaan yang memiliki banyak hutang, mereka tidak terlalu mementingkan pengungkapan tanggung jawab sosial. Mereka lebih mementingkan bagaimana hutang-hutang perusahaan mereka bisa berkurang seiring bertambahnya modal usaha mereka, selain itu juga mungkin akan muncul anggapan bahwa seharusnya perusahaan yang mengungkapkan tanggung jawab sosialnya dengan baik, rasio hutangnya seharusnya bisa lebih rendah. Sebaliknya, perusahaan dengan leverage yang rendah bisa mengungkapkan tanggung jawab sosialnya dengan baik, mungkin dikarenakan aset mereka yang lebih besar dan anggapan-anggapan yang muncul yang diatas sudah disebutkan.

\subsubsection{Jenis Industri Terhadap Tingkat Pengungkapan Islamic Social Reporting}

Jenis industri dalam penelitian ini diklasifikasikan berdasarkan jenis usaha yang dijalankan oleh perusahaan yang dikriteriakan menjadi perusahaan yang msuk dalam industri high profile dan low profile. Hasil uji t, diperoleh angka 7,811 dengan derajat kebebasan $\mathrm{n}-\mathrm{k}=48-5=43$. Maka diperoleh nilai $\mathrm{t}$ hitung 1,681, nilai t hitung $>\mathrm{t}$ tabel. Sedangkan, $p$-value yang diperoleh $0,000<0,05$. Sehingga dapat disimpulkan $\mathrm{H}_{\mathrm{d}}$ ditolak, secara otomatis $\mathrm{H} 1_{\mathrm{d}}$ diterima. Sehingga jenis Industri terbukti signifikan berpengaruh secara positif terhadap tingkat pengungkapan ISRI.

Hasil penelitian ini berbeda dengan hasil penelitian yang dilakukan oleh Othman, et al. (2009) serta Raditya (2012) yang menemukan pengaruh yang tidak signifikan dari variabel bebas jenis industri terhdap tingkat pengungkapan ISR. Namun, hasil penelitian ini konsisten dengan hasil penelitian Widiawati (2012), Nurman (2013) dan Putri (2014) yang membuktikan variabel jenis industri memiliki pengaruh signifikan terhadap tingkat pengungkapan ISR.

Selain itu, dengan adanya Undang-Undang No. 40 tahun 2007 tentang perseroan terbatas pada pasal 74 dan Pasal 66 ayat 2 bagian $C$, perusahaan- 
perusahaan yang termasuk dalam industri high profile khususnya yang bergerak dibidang ekstraktif lebih banyak diperhatikan dan diawasi oleh stakeholder-nya, yaitu masyarakat luas, investor, dan pemerintah dibandingkan perusahaan yang termasuk dalam industri low-profile. Sehingga hipotesis yang dapat dibuktikan dalam penelitian ini, semakin banyak perusahaan yang masuk dalam kategori high profile, maka tingkat pengungkapan ISR akan semakin lebih tinggi. Sebaliknya, semakin banyaknya perusahaan yang masuk dalam kategori low profile, maka akan memperendah tingkat pengungkapan ISR, dikarenakan perusahaan low profile dianggap tidak memiliki kewajiban yang lebih untuk mengungkapkan tanggung jawab sosial perusahaannya karena tidak terlalu banyak diawasi dan diperhatikan.

\subsubsection{Ukuran Dewan Komisaris Terhadap Tingkat Pengungkapan Islamic Social Reporting}

Dewan komisaris dianggap sebagai sebuah mekanisme pengendalian internal tertinggi yang bertanggung jawab untuk memonitor tindakan manajemen puncak. Dikaitkan dengan pengungkapan informasi oleh perusahaan, sejumlah penelitian menunjukkan adanya hubungan positif antara berbagai karakteristik dewan komisaris dengan tingkat pengungkapan informasi oleh perusahaan (Nurkhin, 2009). Ukuran dewan komisaris dalam penelitian ini konsisten dengan penelitian yang dilakukan Sembiring (2005) yaitu jumlah anggota dewan komisaris.

Hasil uji t, diperoleh angka $-2,475$ dengan derajat kebebasan $\mathrm{n}-\mathrm{k}=$ $48-5=43$. Maka diperoleh nilai $\mathrm{t}$ hitung 1,681, nilai $\mathrm{t}$ hitung $<\mathrm{t}$ tabel. Sedangkan, $p$-value yang diperoleh $0,017<0,05$. Sehingga dapat disimpulkan $\mathrm{H} 0_{\mathrm{e}}$ ditolak, secara otomatis secara otomatis $\mathrm{H} 1_{\mathrm{e}}$ diterima. Sehingga, Ukuran Dewan Komisaris terbukti signifikan berpengaruh secara positif terhadap tingkat pengungkapan ISRI. Koefisien ukuran dewan komisaris sebesar -0,011 mengindikasikan bahwa setiap setiap peningkatan nilai ukuran dewan komisaris sebesar $1 \%$ akan mengakibatkan menurunnya tingkat pengungkapan ISR sebesar $0,011 \%$. Penelitian ini konsisten dengan hasil penelitian yang ditemukan oleh Agrytasari (2012) yang membuktikan bahwa dewan komisaris terbukti memiliki hubungan positif terhadap pengungkapan tanggung jawab sosial perusahaan.

Berdasarkan hasil penelitian ini, hipotesis yang dapat dibuktikan yaitu bahwa perusahaan yang memiliki Dewan Komisaris yang lebih banyak, justru cenderung akan lebih rendah dalam melakukan pengungkapan tanggung jawab sosialnya. Hal ini mungkin dikarenakan banyaknya dewan komisaris, akan lebih banyak penambahan-penambahan tekanan yang terkait kebijakan perusahaan. Selain itu juga memungkinkan adanya unsur kepentingan pribadi dari setiap orang. Sehingga semakin sedikit jumlah dewan komisaris, akan semakin tinggi tingkat pengungkapan ISR perusahaan. 


\section{SIMPULAN}

Penelitian ini bertujuan untuk mengetahui faktor-faktor financial dan non financial yang dianggap dapat berpengaruh dalam tingkat pengungkapan Islamic Social Reporting (ISR) dengan bahan observasi pengungkapan laporan tahunan perusahaan Jakarta Islamic Index (JII) periode 2012-2014. Selain itu penelitian ini juga melihat tingkat pengungkapan ISR yang dilakukan oleh perusahaan yang terdaftar dalam JII periode 2012-2014. Penelitian ini menyimpulkan bahwa tingkat ISR perusahaan yang terdaftar pada JII terus mengalami trend positif. Sehingga, kesimpulan yang dapat ditarik dalam penelitian ini, adalah:

1. Peningkatan pengungkapan selama tiga tahun ada pada kisaran $1 \%-3 \%$. Sedangkan, presentase pengungkapan ISR seluruh perusahaan 55,54\%. Pengungkapan dengan skor tertinggi dipegang oleh dua perusahaan BUMN. Namun, diperlukannya penyempurnaan pengungkapan pada tema-tema indeks ISR tertentu seperti pada tema karyawan dan tata kelola perusahaan. Tema tertinggi yang diungkapkan pada perusahaan yang terdaftar di JII adalah tema produk dan jasa $(87,50 \%)$, disusul dengan tema masyarakat $(69,89 \%)$. Kemudian tema lain yang diungkapkan secara berurutan yaitu tema lingkungan $(59,17 \%)$, tema keuangan dan investasi $(55,83 \%)$, tema tata kelola perusahaan $(43,28 \%)$, dan tema karyawan (40,38\%). Pengungkapan untuk poin-poin akun Islami juga perlu mendapat perhatian khusus bagi manajemen. Karena hampir keseluruhan perusahaan tidak mengungkapkan tema yang berkaitan dengan aturan Islam seperti zakat, wakaf, qardhul hasan, serta gharar. Selain itu, variabel independen dalam penelitian ini mampu menjelaskan tingkat pengungkapan ISR sebesar $74,4 \%$.

2. Penelitian ini menemukan bahwa variabel size, profitabilitas, leverage, jenis industri, dan ukuran dewan komisaris terbukti signifikan berpengaruh secara positif terhadap tingkat pengungkapan Islamic social Reporting (ISR), dengan nilai $p$-value masing-masing variabel sebesar 0,027; 0,0000; 0,0000; 0,0000; 0,017. Selain itu R Square $\left(\mathrm{R}^{2}\right)$ yang diperoleh sebesar 74,4\%, yang artinya seluruh variabel independen yang digunakan dalam persamaan regresi ini mampu menjelaskan 74,4\% luas tingkat pengungkapan ISR. Sedangkan sisanya sebesar 25,6\% dipengaruhi oleh variabel lain yang tidak diteliti dalam penelitian ini.

\section{DAFTAR PUSTAKA}

Al Qur'anul Karim dan Terjemah. (2007). Departemen Agama RI. Yayasan Penyelenggara Penerjemah/Penafsir Al-Qur'an Revisi Terjemah oleh Lajnah Pentashih Mushaf Al-Qur'an Departemen Agama RI. Bandung: PT Syaamil Cipta Media. 
Agrytasari, Siska. (2012). Faktor-Faktor yang Berkolerasi Terhadap Pengungkapan Tanggung Jawab Sosial Perusahaan (Corporate Social Responsibility) (Studi pada Bank Umum Syariah di Indonesia Periode 2010). Skripsi tidak dipublikasikan, Depok: STEI SEBI.

Cahya, Bramantya Adhi. (2010). Analisis Pengaruh Kinerja Keuangan Terhadap Tanggung Jawab Sosial Perusahaan (Corporate Social Responsibility) (Studi Pada Bank di Indonesia Periode Tahun 20072008). Skripsi tidak dipublikasikan, Semarang: Universitas Diponegoro.

Dewi, Indah Fitri Karunia. (2012). Analisis Pengaruh Profitabilitas, Leverage, Likuiditas, Ukuran Perusahaan dan Porsi Kepemilikan Publik Atas Saham Terhadap Pengungkapan Islamic Social Reporting Pada Perusahaan Jakarta Islamic Index. Skripsi tidak dipublikasikan, Depok: Universitas Indonesia.

Fact Book IDX 2014. http://www.idx.co.id. Dipetik Agustus 20, 2015.

Fitria, Soraya dan Dwi Hartanti. (2010). Islam dan Tanggung Jawab Sosial: Studi Perbandingan Pengungkapan Berdasarkan Global Reporting Initiative Indeks dan Islamic Social Reporting Indeks. Makalah dalam Simposium Nasional Akuntansi XIII Purwokerto 2010, Universitas Jenderal Sudirman.

Haniffa, Ros. (2002, July). Social Reporting Disclosure: an Islamic Prespective. On Indonesian Management and Accounting Research Vol. 1, No. 2 Jully 2002, 128-146.

Maali, Bassam et al. (2003). Social Reporting by Islamic Banks. On Discussion Papers in Accounting and Finance University of Southampton Number AF03-13 ISSN 1356-3548, 1-39.

Mahadianto, Moh. Yudi dan Adi Setiawan, (2013). Analisis Parametrik Dependensi Dengan Program SPSS. Jakarta: Rajagrafindo Persada.

Mansur, Syuhada. (2012). Pelaporan Corporate Social Responsibility Perbankan Syariah dalam Perspektif Syariah Enterprise Theory (Studi Kasus Pada Laporan Tahunan PT Bank Syariah Mandiri). Skripsi tidak dipublikasikan, Makassar: Universitas Hasanuddin.

Maulida, A. P., Agung Yulianto dan Asrori. (2014). Analisis Faktor-Faktor yang Mempengaruhi Pengungkapan Islamic Social Reporting (ISR). Makalah dalam Simposium Nasional Akuntansi 17 Lombok 2014, Universitas Mataram.

Nurkhin, Ahmad (2009). Corporate Governance dan Profitabilitas; Pengaruhnya Terhadap Pengungkapan Tanggung Jawab Sosial Perusahaan (Studi Empiris Pada Perusahaan yang Tercatat di Bursa Efek Indonesia). Tesis, Semarang: Universitas Diponegoro. 
Nurman, Rifki. (2013). Analisis Faktor-Faktor yang Mempengaruhi Tingkat Pengungkapan Islamic Social Reporting (ISR) Pada Perusahaan yang Terdaftar dalam Indonesia Sharia Stock Index (ISSI). Skripsi tidak dipublikasikan, Depok: Universitas Indonesia.

Othman, Rohana dan Azlan Md Thani. (2010, April). Islamic Social Reporting of Listed Companies in Malaysia. On Internasional Business and Economics Research Journal Volume 9, Number 4, 135144.

Othman, Rohana, et al. (2009, October). Determinants of Islamic Social Reporting Among Top Shariah-Approved Companies in Bursa Malaysia. On Research Journal of International Studies-Issue 12, 120.

Putri, Tria Karina. (2014). Faktor-Faktor yang Mempengaruhi Islamic Social Reporting Perusahaan-Perusahaan yang Terdaftar Pada Indeks Saham Syariah Indonesia (ISSI) Tahun 2011-2012. Skripsi tidak dipublikasikan, Semarang: Universitas Diponegoro.

Raditya, Amilia Nurul. (2012). Analisis Faktor-Faktor yang Mempengaruhi Tingkat Pengungkapan Islamic Social Reporting (ISR) Pada Perusahaan yang Masuk Daftar Efek Syariah (DES). Skripsi tidak dipublikasikan, Depok: Universitas Indonesia.

Santoso, Singgih. (2012). Aplikasi SPSS Pada Statistik Parametrik. Jakarta: Elex Media Komputindo.

Sihombing, Pardomuan (2015). Analisis Regresi Data Panel Menggunakan SPSS. Dipetik November, 06, 2015, dari sumber: http://statistikmenarik.co.id/2015/06/analisis-regresi-data-panelmenggunakan_89.html

Sembiring, E. R. (2005). Karakteristik Perusahaan dan Pengungkapan Tanggung Jawab Sosial: Studi Empiris pada Perusahaan yang Tercatat di Bursa Efek Jakarta. Simposium Nasional Akuntansi 8, 379-395.

Sugiyono, (2010). Metode Penelitian Bisnis. Bandung: Alfabeta.

Undang-Undang No. 25 Tahun 2007 tentang Penanaman Modal.

Undang-Undang No. 40 Tahun 2007 tentang Perseroan Terbatas.

Widaryanti. (2007, Desember). Analisis Pengaruh Pengungkapan Tanggung Jawab Sosial Perusahaan Terhadap Kinerja Keuangan (Studi Pada Perusahaan yang Terdaftar di Bursa Efek Jakarta). Dalam Jurnal Fokus Ekonomi Vol. 2, No. 2, 30-50.

Widiastuti, Eka. (2014). Pengaruh Faktor-Faktor Non Financial Terhadap Tingkat Islamic Social Reporting Disclosure Perbankan Syariah 
Indonesia Tahun 2010-2012. Skripsi tidak dipublikasikan. Depok: STEI SEBI.

Widiawati, Septi. (2012). Analisis Faktor-Faktor yang Mempengaruhi Islamic Social Reporting Perusahaan-Perusahaan yang Terdapat pada Daftar Efek Syariah Tahun 2009-2011. Skripsi tidak dipublikasikan, Semarang: Universitas Diponegoro.

www.idx.co.id. Perusahaan yang Terdaftar pada Jakarta Islamic Index. (2012, 2013, 2014). Annual Report Perusahaan yang Terdaftar pada Jakarta Islamic Index. Dipetik Agustus 20, 2015, dari situs resmi Bursa Efek Indonesia: http://www.idx.co.id 